\title{
Identification of the Microbial Population found in Water Sources in and around San Salvador Island, Bahamas
}

\author{
Michel Pelletier, James M. Haynes, \\ Ashley M. Dungan, and John Kroeckel \\ The College at Brockport, \\ State University of New York, Brockport, NY ${ }^{1}$
}

\begin{abstract}
San Salvador Island in The Bahamas is home to approximately 1,200 people, and a popular vacation destination. In order to expand our knowledge of the bacterial population found on and around the island, and to assess possible health risks, we analyzed and identified the cultivable bacterial population found in several lakes and ponds throughout the island. The sites tested were located on the northern, north-eastern, eastern, and western districts, as well as one lake located inland. Ten sites with varying salinity, levels of oxygen, visibility, and distance from the ocean were analyzed. The nature of the bacteria present in these sites was identified by microscopy, as well as a series of biochemical tests based on bacterial metabolism. Seven bacterial species, predominantly from the genera Staphylococcus and Klebsiella were identified. Most bacteria identified are part of the normal microbiota of the skin and the gastro-intestinal tract of human and mammals, and should not be considered a danger for the health of the majority of the population and tourists of the island. We also isolated bacteria capable of fixing atmospheric nitrogen, a hallmark of marine bacterial populations. Overall, this study enabled us to add to the repertoire of bacterial species isolated and identified in the diverse marine environments found on San Salvador Island.
\end{abstract}

\section{INTRODUCTION}

San Salvador Island, located some $640 \mathrm{~km}$ from Miami, Florida, is one of the 700 islands that make up The Bahamas archipelago (Gerace, Ostrander, \& Smith, 1998). Microbiological research in the coastal waters in and around San Salvador, Bahamas is essential for multiple reasons. Its geology, the presence of many inland ponds and lakes, as well as the variability in the salinity of the lakes, make San Salvador Island stand apart from most islands found in The Bahamas (Park, 2012). The island comprises lakes with very high salinity such as Salt Pond (Paerl, Steppe, Buchan, \& Potts, 2003), normal and low salinity lakes such as Storr's Lake as well as ponds and lakes located on the United Estates area (Park, 2012; Gerace et al., 1998). Most important, this region has not been fully studied, and the enumeration and

\footnotetext{
${ }^{1}$ Michel Pelletier, Assistant Professor, Department of Biology; James M. Haynes, Professor, Department of Environmental Science and Biology; Âshley M. Dungan and John Kroeckel, Undergraduate students, Department of Biology, The College at Brockport, State University of New York, Brockport, NY 11420-2973.

Corresponding author: mpelleti@brockport.edu

APA reference: Pelletier, M., Haynes, J. M., Dungan, A.M., \& Kroeckel, J. (2014). Identification of the microbial population found in water sources in and around San Salvador Island, Bahamas. The International Journal of Bahamian Studies, 20(1), 27-37. https://doi.org/10.15362/ijbs.v20i1.196
}

(C) M. Pelletier et al., 2014. Journal compilation (c)The International Journal of Bahamian Studies, 2014 
determination of its microbial flora has become very important after the addition of a world class all-inclusive resort to the island in the early 1990's ("San Salvador," 2013). Instead of developing new waste removal methods, residents resorted to dumping waste and garbage into the ocean (Mylroie \& Thoren, 2007). This could potentially have resulted in an increase in harmful bacteria and other microorganisms in the water on and around the island. Sadly, 20 years later not much has changed. Furthermore, as a result of San Salvador's geography, and the fact that the island sits directly above its fresh water table (Shaklee, 1994), pollutants that get in the soil or marine waters could directly infect the population on the island. By investigating fluctuations in these microbial environments, especially information about numbers, biomass, and activity, it becomes possible to more rapidly evaluate the state of health of other dependent ecosystems. Scientific data that provides supporting evidence of the existence of disease-causing microorganisms already present in the coastal waters, which could easily reach the water table, could lead to reform among the citizens in their attitudes and regulated procedures for garbage and waste removal on the island, and lead to longterm positive healthcare benefits.

The water cycle represents an obvious mode of disease transmission, which makes water supply sanitation the most essential feature for the prevention of infection. Recent studies by the World Health Organization (2014) have determined that more than approximately four million people die worldwide from water associated diseases, mostly intestinal infections, every year. The major health risk is associated with the consumption of water contaminated with human and animal fecal matter. This is true for both freshwater and coastal water. Diseases associated with consumption of contaminated water include cholera, gastroenteritis, typhoid fever, shigellosis, and severe diarrhea. Bacteria such as Clostridium perfringens, Shigella sonnei, Escherichia coli, Salmonella typhi, and Vibrio cholerae are microorganisms associated with water supply known to cause diseases (Cabral, 2010, United States Environmental Protection Agency, 2012). In addition, viruses such as adenoviruses, enteroviruses, as well as hepatitis viruses $\mathrm{A}$ and $\mathrm{E}$ are well-established causative agents of waterborne diseases including gastroenteritis, meningitis, respiratory illnesses, and hepatitis (La Rosa, Fratini, della Libera, Iaconelli, \& Muscillo, 2012). Some protozoa found in water, notably Cryptosporidium parvum, are also responsible for gastrointestinal diseases (Baldursson \& Karanis, 2011). Analysis of the water quality has previously been performed at several sites on San Salvador Island (Mylroie \& Thoren, 2007). The study focused on coliforms, most notably Escherichia coli. The authors showed a direct correlation between the levels of coliforms, which is indicative of water contamination, and human population density.

In addition to potential human pathogens, oceans contain an abundance of nitrogenfixing bacteria (Zehr, 2011). Nitrogen fixation, the reduction of atmospheric nitrogen into assimilable ammonium, is primarily performed by cyanobacteria (Zehr, 2011). Among the many species of cyanobacteria present in marine environments, Trichodesmium appears to be the most abundant (Mahaffey, Michaels, \& Capone, 2005). Interestingly, a study aimed at the identification of cyanobacteria present in the hypersaline Salt Pond located in the eastern sector of San Salvador Island has shown the predominance of filamentous cyanobacteria of the order Oscillatoriales (Yannarell, Steppe, \& Paerl, 2006).

The objective of this study was to further enhance existing knowledge of the bacterial population present in and around San Salvador Island in relation to environmental 
factors and pathogenesis in the human population. We proceeded to identify the major bacterial species found in ten different sites. Water samples were collected from sites varying in salinity, dissolved oxygen concentration, and access to the ocean, and the nature of the major cultivable bacterial populations determined by microscopic observations and biochemical tests.

\section{METHODS Sample Collection.}

Three samples were taken from each of the ten locations shown in Figure 1 and listed in Table 1. Two separate isolations and analyses were performed on each sample. Samples were collected from districts in the north: Graham's Harbour (\#6 on Fig. 1); north east: Reckly Hill (\#2), United Estates Pond South (\#8) and North (\#7); east: Storr's Lake (\#9), Salt Pond (\#10); and west: Telephone Pole (\#1), Failed Marina (\#3), Bamboo Swamp $(\# 4)$ : as well as from Long Lake (\#5), located inland. Aseptic technique was followed during the sample collection. Sample collection equipment on location was kept sterile until the sampling time. This was achieved by keeping all equipment in its original sterile packaging and opening it only when ready to begin sampling. Visibility, conductivity, $\mathrm{pH}, \quad$ dissolved oxygen concentration, water temperature, air temperature, sampling time, and tide were recorded for each location sampled. Conductivity, $\mathrm{pH}$, and dissolved oxygen concentration were measured using an Orion Star A329 pH/ISE/Conductivity/Dissolved Oxygen Portable Multiparameter Meter (Thermo Scientific). Air temperature and water temperature were measured using a PT100 RTD Handheld Thermometer (Omega). Tide levels were recorded from visual observations at each location and from tide charts provided by the Gerace Field Station. Visibility was assessed using a Secchi disk following the guidelines established by the United States
Environmental Protection Agency (Table 1). Approximately $200-300 \mathrm{ml}$ of water was taken in triplicate from each location using sterile polypropylene bottles, carried into Styrofoam coolers packed with ice, and stored in a refrigerator at $4{ }^{\circ} \mathrm{C}$ within $1-2$ hours of collection.

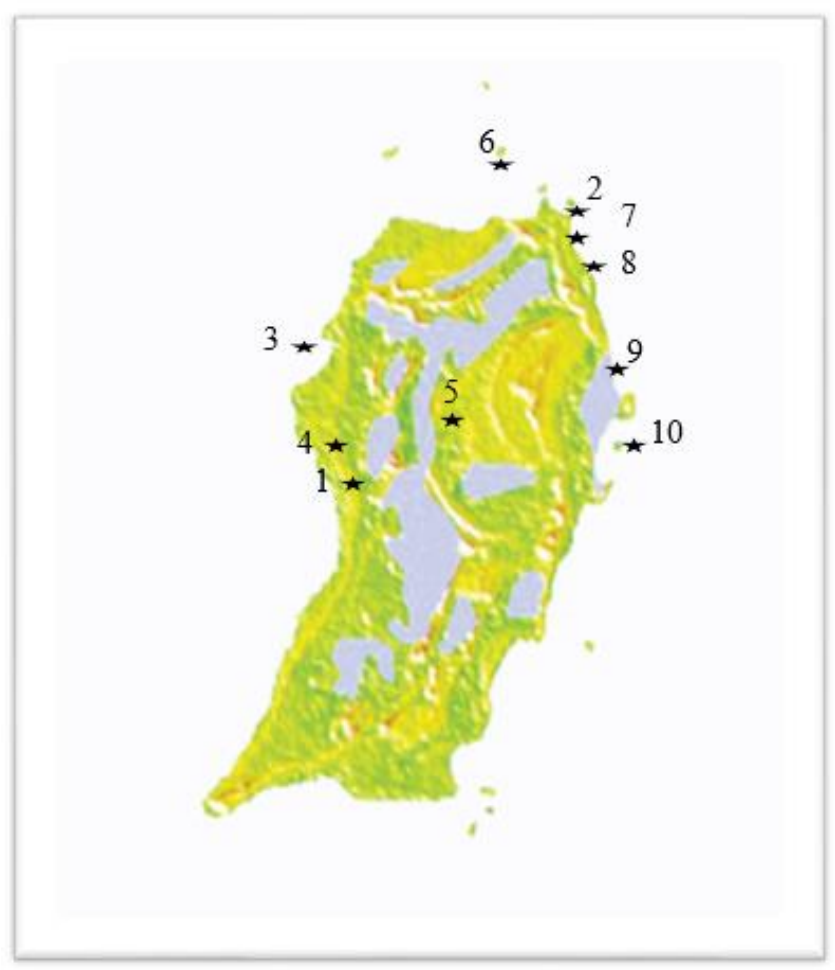

Figure 1. Map of San Salvador Island with sampled sites used for this study. The exact location of the sampled sites is indicated in Table 1

\section{Microbial cultures.}

Once we returned to our laboratory in Brockport, NY, the samples (3 separate samples analyzed in duplicate per each of the 10 collection sites, for a total of 60 samples) were filtered (200-300 ml) through $0.22 \mu \mathrm{m}$ polyvinylidene fluoride (PVDF) filters (Millipore). The filters were then deposited at the surface of Brain-Heart infusion (BHI) agar and Eosin-Methylene blue (EMB) agar (Biosciences), and incubated at $37{ }^{\circ} \mathrm{C}$ for 48 hours. Isolated colonies were obtained by restreaking (subculture) onto BHI agar (BD Biosciences). The presence of coliforms was determined by streaking onto the selective 
EMB agar (BD Biosciences). The ability of bacteria from the genus Staphylococcus to ferment mannitol with production of acid was examined by plating onto mannitol-salt agar (MSA) medium. The presence in the MSA of $7.5 \%$ sodium chloride is selective for bacteria of the genus Staphylococcus. In addition, the presence of phenol red as a $\mathrm{pH}$ indicator allows researchers to determine whether the bacteria can ferment mannitol with production of acid ( $S$. aureus) or is unable to ferment mannitol (S. epidermidis).

To select for nitrogen-fixing bacteria, $10 \mathrm{ml}$ of water sample was mixed with an equal volume of enrichment medium, which contained $4 \%$ glucose, $4 \% \quad \mathrm{CaCO}_{3}, 0.2 \%$ $\mathrm{K}_{2} \mathrm{HPO}_{4}$, and $0.1 \% \mathrm{MgSO}_{4} .7 \mathrm{H}_{2} \mathrm{O}$. Cultures were incubated at $27{ }^{\circ} \mathrm{C}$ for 2 weeks until a frothy layer of bacterial growth was visible. Cultures were then plated on selective medium containing $2 \%$ glucose, $2 \% \mathrm{CaCO}_{3}$, $0.08 \% \quad \mathrm{KH}_{2} \mathrm{PO}_{4}, \quad 0.1 \% \quad \mathrm{~K}_{2} \mathrm{HPO}_{4}, \quad 0.05 \%$ $\mathrm{MgSO}_{4} 0.7 \mathrm{H}_{2} \mathrm{O}, 0.01 \% \mathrm{FeSO}_{4}$, and $2 \%$ agar.

\section{Biochemical tests.}

Several biochemical tests were performed on isolated colonies for further identification.

1. Carbohydrate fermentation. The ability to ferment carbohydrates with production of acid was determined by inoculating $3 \mathrm{ml}$ of a nutrient broth containing bromocresol purple as a $\mathrm{pH}$ indicator, as well as the appropriate carbohydrate at a final concentration $1 \%$ with a single colony, and incubating at $37^{\circ} \mathrm{C}$ for 48 hours. In the presence of acidic products resulting from fermentation, the broth will turn yellow $(\mathrm{pH} \leq 5.2)$, indicative of a positive result. In the absence of fermentation, the broth will remain purple.

2. Methyl Red (MR) test. To determine whether the isolated bacteria could oxidize glucose with the production of stable acidic products, $3 \mathrm{ml}$ of a buffered peptone broth containing glucose at a final concentration of $3 \%$ was inoculated with a single colony.
Following incubation at $37{ }^{\circ} \mathrm{C}$ for 48 hours, five drops of the $\mathrm{pH}$ indicator $\mathrm{MR}(0.02 \%$ solution) was added. In the presence of acidic fermentation products, the broth will turn red ( $\mathrm{pH} \leq 4.4)$. On the other hand, a yellow coloration $(\mathrm{pH} \geq 6.2)$ indicates a negative MR test.

3. Vogues-Proskauer (VP) test. The VP test is used to detect the presence of acetoin, a neutral end product of glucose metabolism. Three $\mathrm{ml}$ of a buffered peptone broth containing $3 \%$ glucose was inoculated with a single colony. Following incubation at $37^{\circ} \mathrm{C}$ for 48 hours, five drops of Barritt's reagent $\mathrm{A}$ (5\% (wt/vol) $\alpha$-naphthol in absolute ethanol) and five drops of Barritt's reagent B (40\% (wt/vol) potassium hydroxide) (both from Gibson Bioscience) were added and the tube incubated at room temperature $\left(22-25^{\circ} \mathrm{C}\right)$ for $15 \mathrm{~min}$. The presence of a pink to cherry coloration indicates a positive result (production of acetoin from glucose).

4. Hydrogen sulfide production. To determine the ability of microorganisms to produce hydrogen sulfide $\left(\mathrm{H}_{2} \mathrm{~S}\right)$ from substrates such as the sulfur-containing amino acids or inorganic sulfur compounds, a Sulfide Indole Motility (SIM) medium was inoculated. This semi-solid medium contains peptones and sodium thiosulfate $\left(\mathrm{Na}_{2} \mathrm{~S}_{2} \mathrm{O}_{3}\right)$ as substrates, as well as ferrous ammonium sulfate $\left(\mathrm{Fe}\left(\mathrm{NH}_{4}\right)_{2}\left(\mathrm{SO}_{4}\right)_{2} \cdot 6 \mathrm{H}_{2} \mathrm{O}\right)$ that react with any $\mathrm{H}_{2} \mathrm{~S}$ produced to form a black ferrous sulfate (FeS) precipitate. A sterile inoculating needle was used to inoculate a SIM medium using the stab technique. The presence of a black $\mathrm{FeS}$ precipitate after incubation at $37{ }^{\circ} \mathrm{C}$ for 48 hours denotes a positive result.

5. Motility. The semi-solid state of the SIM medium also allowed evaluation of the motility of the isolated bacteria. The same tube used for the $\mathrm{H}_{2} \mathrm{~S}$ production test was examined for cloudiness extending out in the surrounding medium, which is an indication 
of the growth of a motile bacterium.

6. Indole production. The ability to degrade tryptophan into indole was also determined by inoculation of the SIM medium using the stab technique. The inoculated medium was incubated at $37^{\circ} \mathrm{C}$ for 48 hours, and 10 drops of Kovac's reagent (Gibson Bioscience) were added. If indole is produced during bacterial growth, a red ring will appear at the surface of the medium.

7. Starch hydrolysis. For bacterial identification, a solid medium containing starch was inoculated in order to detect the presence of the enzymes amylase and maltase capable of hydrolyzing starch. Following incubation at $37^{\circ} \mathrm{C}$ for 48 hours, the plate was flooded with Lugol's iodine solution. Starch hydrolysis is visualized by the presence of a clear zone around the bacterial growth within 30 seconds.
8. Novobiocin resistance. Resistance to the antibiotic novobiocin was determined by plating onto a Mueller-Hinton II medium in the presence of a disk containing $30 \mu \mathrm{g}$ novobiocin, and measuring the diameter of the zone of growth inhibition around the disk after incubation at $37^{\circ} \mathrm{C}$ for 48 hours.

\section{Identification of bacteria.}

Identification of the bacterial species isolated from the different sites was performed by compiling the results of the Gram stain and biochemical tests, and by using identification keys found in Bergey's Manual of Determinative Bacteriology (Holt, 2000).

\section{RESULTS}

In order to assess the variability between the different sampled sites, we recorded several physical parameters as described in the Methods section. Table 1 shows the physical data collected on the field.

Table 1

Physical parameters of the different collection sites on San Salvador Island

\begin{tabular}{|c|c|c|c|c|c|c|c|c|c|}
\hline Location & $\begin{array}{l}\text { Visibility } \\
(\mathrm{m})\end{array}$ & $\begin{array}{c}\text { Conductivity } \\
(\mathrm{mS} / \mathrm{cm})\end{array}$ & $\mathrm{pH}$ & $\begin{array}{l}\mathrm{O}_{2} \\
(\%) \\
\end{array}$ & $\begin{array}{l}\text { Water } \\
\mathrm{T}\left({ }^{\circ} \mathrm{C}\right) \\
\end{array}$ & $\begin{array}{c}\text { Air } \\
\mathrm{T}\left({ }^{\circ} \mathrm{C}\right) \\
\end{array}$ & Time & Tide & $\begin{array}{l}\text { Distance from } \\
\text { ocean (miles) }\end{array}$ \\
\hline 1) Telephone Pole & 30 & 52.8 & 8.43 & 98 & 23.2 & 26.7 & $9: 30 \mathrm{AM}$ & Low & 0.1 \\
\hline 2) Reckly Hill & $<1$ & 64.2 & 8.45 & 119 & 19.5 & 26.0 & 9:00 AM & Low $\rightarrow$ High & 0.4 \\
\hline 3) Failed Marina & $<0.1$ & 38.6 & 8.39 & 84 & 21.1 & 25.8 & $10: 40 \mathrm{AM}$ & High & 0.1 \\
\hline 4) Bamboo Swamp & 0.15 & 9.05 & 8.72 & 113 & 21.7 & 26.0 & $11: 00 \mathrm{AM}$ & High & 0.1 \\
\hline 5) Long Lake & 5 & 60.7 & 8.43 & 113 & 22.7 & 26.1 & 01:30 PM & High $\rightarrow$ Low & 2.0 \\
\hline 6) Graham's Harbour & 5 & 55.7 & 8.42 & 100 & 24.7 & 26.9 & 1:00 PM & High & 0 \\
\hline $\begin{array}{l}\text { 7) United Estates } \\
\text { Pond-North side }\end{array}$ & 0.05 & 53.6 & 8.83 & 60 & 24.5 & 24.9 & $9: 15 \mathrm{AM}$ & Low & 0.5 \\
\hline $\begin{array}{l}\text { 8) United Estates } \\
\text { Pond-South side }\end{array}$ & 0.05 & 59.3 & 8.96 & 75 & 24.3 & 24.9 & $9: 20 \mathrm{AM}$ & No tide & 0.5 \\
\hline 9) Storr's Lake & 0.2 & 58.5 & 8.60 & 101 & 24.4 & 25.5 & $9: 30 \mathrm{AM}$ & Low & 0.3 \\
\hline 10) Salt Pond & 0.1 & 145.8 & 8.20 & 85 & 29.2 & 27.2 & $11: 00 \mathrm{AM}$ & Low $\rightarrow$ High & 0.1 \\
\hline
\end{tabular}

The nature of the sampled sites varied primarily in distance from the ocean, salinity/conductivity, and percentage of dissolved oxygen. Some samples were taken at sites directly on or very close to the ocean (e.g. Graham's Harbour, Telephone Pole, 
Failed Marina, Bamboo Swamp, and Salt Pond), while others were collected farther inland (Reckly Hill, United Estates, Storr's Lake, and Long Lake). The salinity of the different samples varied from very low $(9.05$ $\mathrm{mS} / \mathrm{cm}$, Bamboo Swamp) to very high (145.8 $\mathrm{mS} / \mathrm{cm}$, Salt Pond). Most samples contained good levels of dissolved oxygen, although the United Estates site has significantly lower amounts.

Using the approach described in the Methods section, we were able to identify several bacteria from all sampled sites. The list of the bacteria isolated at each site is presented in Table 2.

Table 2.

Identification of bacterial populations at sampled sites

\begin{tabular}{|c|c|}
\hline Location & Microorganism isolated \\
\hline 1) Telephone Pole & Staphylococcus aureus \\
\hline 2) Reckly Hill & Staphylococcus epidermidis \\
\hline \multirow{3}{*}{ 3) Failed Marina } & Klebsiella pneumoniae subspecies \\
\hline & ozaenae \\
\hline & Enterococcus sp. \\
\hline \multirow{3}{*}{ 4) Bamboo Swamp } & Klebsiella pneumoniae subspecies \\
\hline & ozaenae \\
\hline & Nitrogen-fixing bacteria \\
\hline 5) Long Lake & Staphylococcus epidermidis \\
\hline 6) Graham's Harbour & Staphylococcus epidermidis \\
\hline $\begin{array}{l}\text { 7) United Estates Pond- } \\
\text { North side }\end{array}$ & Corynebacterium xerosis \\
\hline \multirow{2}{*}{$\begin{array}{l}\text { 8) United Estates Pond- } \\
\text { South side }\end{array}$} & Staphylococcus epidermidis \\
\hline & Micrococcus luteus \\
\hline 9) Storr's Lake & Staphylococcus epidermidis \\
\hline \multirow{2}{*}{ 10) Salt Pond } & Brevibacillus brevis \\
\hline & Nitrogen-fixing bacteria \\
\hline
\end{tabular}

Staphylococcus epidermidis. S. epidermidis was isolated from several locations on the island, namely Reckly Hill, Long Lake, Graham's Harbour, United Estates Pond-
South Side, and Storr's Lake. Gram stains of isolated colonies obtained from these five locations following growth on BHI medium revealed that they were all Gram-positive cocci arranged in clusters, characteristic of the genus Staphylococcus and Micrococcus. This was confirmed by the ability of those cells to express the enzyme catalase. In addition, as all of the isolated colonies were either white or beige, we concluded that they belong to the genus Staphylococcus rather than Micrococcus, which exhibits a yellow pigmentation. The colonies grew on MSA but did not turn the medium from red to yellow, indicating the inability to ferment mannitol with production of acid. At this point, the identity of the bacteria isolated was limited to either $S$. epidermidis or $S$. saprophyticus. However, the fact that the bacteria could grow in the presence of the antibiotic novobiocin allowed us to conclude that $S$. epidermidis had been isolated from these five locations.

Staphylococcus aureus. $S$. aureus was present in the water sample obtained from the Telephone Pole location. Microscopic observation of an isolated colony obtained on BHI medium showed the presence of clusters of Gram-positive cocci. The same tests that were performed to identify $S$. epidermidis were also carried out. The results were the same, except that the bacteria isolated from the Telephone Pole area could ferment mannitol with the production of acid. This led us to conclude that this bacterium was the pathogenic $S$. aureus.

Klebsiella pneumoniae subspecies ozaenae. This enteric bacterium was isolated from both the Failed Marina and the Bamboo Swamp. By microscopy, we observed Gram-negative rods that did not form endospores. Inoculation of an EMB medium resulted in the growth of pink colonies, indicating fermentation of lactose with little acid production. To further identify this bacterium, a SIM medium was inoculated. Following incubation for 48 hours, no indole 
was detected. The bacterium was non-motile and produced a significant amount of $\mathrm{H}_{2} \mathrm{~S}$. In addition, the MR test was positive and the VP test negative. Taken together, these results indicate that $K$. pneumoniae subsp ozaenae was isolated from these two locations.

Enterococcus sp. In addition to $K$. pneumoniae and $S$. fonticola, the Failed Marina also contained bacteria of the genus Enterococcus. This was determined by the presence of Gram-positive cocci unable to express catalase, eliminating the possibility that they were from the genus Staphylococcus or Micrococcus. In addition, the inability of the bacteria to lyse red blood cells, combined with the fact that cells were found either in pairs or as single cells, but not as chains, indicated that it belonged to the genus Enterococcus rather than Streptococcus.

Corynebacterium xerosis. C. xerosis was isolated from the north side of the United Estates Pond. This Gram-positive rod-shaped bacterium was also catalase positive. The majority of Gram-positive rods that express the enzyme catalase belong to the genus Bacillus. However, we found that the bacterium isolated from this location was unable to form endospores, indicating that it belongs to a different genus. In addition, microscopic observations revealed the characteristic club-shaped morphology generally associated with the genus Corynebacterium.

Micrococcus luteus. M. luteus was present in the sample acquired from the United Estates Pond-South Side. The presence of yellow colonies on BHI, combined with microscopic observations showing the presence of Grampositive cocci arranged in clusters, first suggested that these bacteria could be from the genus Staphylococcus or Micrococcus. This was confirmed by the ability of the isolated cells to catalyze the conversion of hydrogen peroxide to water and oxygen through the action of catalase. Further biochemical tests showed that the bacteria were unable to ferment mannitol or glucose, indicative of Micrococcus luteus.

Brevibacillus brevis. B. brevis was found exclusively in the Salt Pond. Gram stain of isolated colonies revealed the presence of Gram-positive rods with visible endospores. Additionally, the isolated bacterium was able to hydrolyze starch. Both MR and VP were negative, and the bacterium did not produce acid from arabinose fermentation. All these characteristics, and the fact that the isolate was obtained from high salinity water confirmed the identity of the bacterium as $B$. brevis.

We finally attempted to isolate nitrogen-fixing bacteria from all 10 locations. This was achieved by inoculating a liquid enrichment medium that did not contain any source of nitrogen. The only microorganisms able to grow were those able to obtain and fix atmospheric nitrogen $\left(\mathrm{N}_{2}\right)$. Growth was visible in the broths inoculated with water samples obtained from the Salt Pond and the Bamboo Swamp. Microscopic observations revealed the presence of Gram-negative rods, suggesting that those bacteria were either cyanobacteria, or from the genus Azotobacter. Beijerinckia, Klebsiella

\section{DISCUSSION}

The conductivity values were of particular interest. Conductivity measures the total dissolved ion concentrations (TDI) in a water sample, and is thus a measurement of salinity (Emery \& Thomson, 2004). The average ocean conductivity has been measured to be approximately 54 milliSiemens per centimeter $(\mathrm{mS} / \mathrm{cm})$, or $3.5 \%$. San Salvador however is home to a wide variety of environments, ranging from nearly fresh water (Bamboo swamp, $9.05 \mathrm{mS} / \mathrm{cm}$ or $0.6 \%$ ) to three times the normal ocean conductivity (Salt Pond, $145.8 \mathrm{mS} / \mathrm{cm}$ or $9.3 \%$ ). In addition, values for dissolved oxygen concentration are very high at most locations. In these environments, 
it is unlikely that anaerobic bacteria are unable to survive (Bauman, 2014).

Isolation and identification of the bacterial flora around San Salvador Island revealed minimal health risk associated with water contamination. The bacterial genus that was recovered from most sites was Staphylococcus. These Gram-positive cocci are members of the normal microbial flora of human and other warm-blooded animals. They live mostly on the skin and mucous membranes of these hosts, but they have also been isolated from animal products such as meat, milk and cheese, and other sources such as soil, sand, seawater, and fresh water (Balows, Truper, Dworkin, Harder, \& Schleifer, 1991). The presence of $S$. epidermidis in those locations should not be regarded as a health risk. However, although a normal component of the human microflora, $S$. epidermidis is an opportunistic pathogen often associated with wound infections (Vos et al., 2009, p. 406). In extreme cases, the bacterium can gain entry into the bloodstream through major wounds and punctures, multiply and form clots. They can then block or weaken the blood vessels, causing an aneurysm (Nester et al., 2012, p. 523). As for Staphylococcus aureus, it is also a member of the normal flora of humans, found on nasal passages, skin and mucous membranes. It is, however, an important human pathogen, responsible for a wide range of skin infections such as boils, impetigo and cellulitis. In addition, $S$. aureus is a major cause of food poisoning (Nester et al., 2012, p. 756) and toxic shock syndrome (p. 620).

Klebsiella pneumoniae subspecies ozaenae was isolated from two sites: Failed Marina and Bamboo Swamp. This short, non-motile straight rod occurs singly, in pairs, and in short chains. A member of the normal intestinal flora of humans and animals, it is also an opportunistic pathogen found in feces of man and animals without any symptoms of disease, and in water, sewage, soil, and food.
K. pneumoniae ozaenae is associated with an upper respiratory infection, ozena, that leads to necrosis and atrophy of the nasal mucosa with resultant nasal discharge (Garrity, Brenner, Krieg, \& Staley, 2009). Although $K$. pneumoniae ozaenae is not a concern for the general population, its presence in these two samples indicates possible contamination with fecal material that may carry pathogenic bacteria in small numbers. $K$. pneumoniae ozaenae is also routinely isolated from nonfecal sources such as plants, plant byproducts, and decaying trees (Garrity et al., 2009).

A bacterium belonging to the genus Enterococcus was also isolated from the Failed Marina location. Similarly to $K$. pneumoniae ozaenae, Enterococcus is part of the normal flora of the intestinal tract in humans and animal, but can also cause opportunistic infections, most notably urinary tract infections, bacteremia, intra-abdominal abscesses, and kidney infections (Vos et al., 2009, p. 595). The presence of Enterococcus in water is an indication of fecal contamination. Species that are the most often isolated from contaminated water include E. faecalis, E. faecium, E. durans, and E. hirae (Godfree, Kay, \& Wyer, 1997).

Isolated from the north side of the United Estates Pond, Corynebacterium xerosis is considered a normal non-pathogenic microorganism found on human skin and mucous membranes. It usually colonizes moist areas on the skin. There are very limited reports of $C$. xerosis being associated with human infections (Funke, von Gravenitz, Clarridge, \& Bernard, 1997; Palacios et al., 2010). Cases of endocarditis, pneumonia, and skin infections caused by $C$. xerosis have been reported in immunocompromised individuals (Lipsky, Goldberger, Tompkins, \& Plorde, 1982). Essentially, only three species are known to be pathogens: $C$. diphtheriae, $C$. ulcerans, and C. pseudotuberculosis. These three species produce diphtheria toxin, a 
powerful exotoxin that is released by the bacteria growing in the throat, resulting in the death of these epithelial cells (Whitman et al., 2012, pp. 247-250).

Micrococcus luteus was isolated from the south side of the United Estates Pond. Mammalian skin, including human, is the natural habitat for $M$. luteus. It is also commonly found in some marine animals such as some fish, sharks, crustacean shellfish, shrimps, and prawns (Bannerman, \& Peacock, 2007). The presence of this bacterium is not unexpected, and it should not be considered a health risk. It is however an opportunistic pathogen. M. luteus has been reported as the causative agent in cases of intracranial abscesses, pneumonia, septic arthritis, endocarditis, and meningitis (Vos et al., 2009, p. 571).

Formerly known as Bacillus brevis, Brevibacillus brevis is a Gram-positive rod mostly found in soil, air, water, and decaying matter, and rarely associated with infectious diseases. Because of their ability to form highly-resistant endospores, members of the genus Bacillus are ubiquitous and can be found in extreme environments (Vos et al., 2009, p. 21). We have determined that the Salt Pond had a concentration of total dissolved ions of $9.5 \%$. Although most microorganisms are unable to survive in these high salt conditions, $B$. brevis is likely to be able to withstand these conditions (Hecker, \& Völker, 2001).

Finally, it is noteworthy that we were able to isolate nitrogen-fixing bacteria from two locations: the Bamboo Swamp, and the Salt Pond. Nitrogen fixation is defined as the reduction of atmospheric nitrogen $\left(\mathrm{N}_{2}\right)$ to ammonia $\left(\mathrm{NH}_{3}\right)$ by microorganisms. Many microorganisms, mainly cyanobacteria, are able to carry out nitrogen fixation in oceans (Zehr et al., 2001). Cyanobacteria represent a phylum of morphologically diverse Gramnegative bacteria. Some exhibit typical bacterial shapes such as cocci, rods, spirilla, while others form filaments. In both Bamboo Swamp and Salt Pond, we observe Gramnegative rods, as it would be expected for Cyanobacteria. In addition, Klebsiella pneumoniae is able to fix nitrogen under anaerobic conditions or in the presence of low oxygen concentrations (Hill, Turner, \& Bergersen, 1984). Although it has previously been shown that the majority of nitrogenfixing bacteria in marine environments are cyanobacteria (Zehr et al., 2001), it remains possible that the nitrogen-fixing bacterium that we isolated from these two locations is $K$. pneumoniae rather than cyanobacteria.

\section{CONCLUSIONS}

By microscopic observations and biochemical testing, we have been able to determine that, although bacteria were present in significant numbers in all sites tested, the vast majority represent the normal microbial flora of the skin or the intestinal tract of human and other mammals. Consequently, none of the bacteria isolated represent an important health risk for the native population and tourists of San Salvador Island. These results help to improve our knowledge of the bacterial population present in diverse water sources on and around San Salvador Island. Our findings could also contribute to the development of a research database for microbial activity in the coastal environment of The Bahamas.

\section{REFERENCES}

Baldursson, S., \& Karanis, P. (2011).

Waterborne transmission of protozoan parasites: Review of worldwide outbreaks: an update, 2004-2010. Water Research,
45(20), 6603-6614.

doi:10.1016/j.watres.2011.10.013

Balows, A., Truper, H. G., Dworkin, M., Harder, W., \& Schleifer, K.-H. (Eds.). (1991). The genus Staphylococcus. In The 
Prokaryotes: a Handbook on the biology of bacteria: Ecophysiology, isolation, identification, application (2nd. Ed., pp. 1369-1420). New York: Springer.

Bannerman, T. L., \& Peacock, S. J. (2007). Staphylococcus, Micrococcus, and other catalase-positive cocci. In P. R. Murray, E. J. Baron, J. H. Jorgensen, M. L. Landry \& M. A. Pfaller (Eds.), Manual of clinical microbiology (9th ed., pp. 390-404). Washington, DC: ASM Press. Washington.

Bauman, R. W. (2014). Microbiology with diseases by taxonomy (4th ed.). Harlow, Essex, England: Pearson Education.

Cabral, J. P. S. (2010). Water microbiology, bacterial pathogens and water. International Journal of Environmental Research and Public Health, 7(10), 36573703. doi:10.3390/ijerph7103657

Emery, W. J., \& Thomson, R. E. (2004). Data analysis methods in physical oceanography. 2nd rev. ed. Amsterdam: Elsevier.

Funke, G., von Graevenitz, A., Clarridge, J. E, \& Bernard, K. A. (1997). Clinical microbiology of coryneform bacteria. Clinical Microbiology Reviews, 10(1), 125-159.

Garrity, G. M., Brenner, D. J., Krieg, N. R., \& Staley, J. T., (Eds.). (2009). Bergey's manual of systemic bacteriology, volume 2. (2nd ed.) New York: Springer.

Gerace, D. T., Ostrander, G. K., \& Smith, G. W. (1998). San Salvador, Bahamas. In B. Kjerfve (Ed.), CARICOMP Caribbean coral reef, seagrass and mangrove sites (pp. 229-246). Paris: UNESCO. Retrieved from http://www.unesco.org/csi/pub/papers/pape rs3.pdf

Godfree, A. F., Kay, D., \& Wyer, M. D. (1997). Faecal streptococci as indicators of faecal contamination in water. Journal of
Applied Microbiology, 83(S1), 110-119. doi:10.1046/j.1365-2672.83.s1.12x

Hecker, M., \& Völker, U. (2001). General stress response of Bacillus subtilis and other bacteria. Advances in microbial physiology, 44, 35-91. doi:10.1016/S00652911(01)44011-2

Hill, S., Turner, G. L., \& Bergersen, F. J. (1984). Synthesis and activity of nitrogenase in Klebsiella pneumoniae exposed to low concentrations of oxygen. Journal of general microbiology, 130(5), 1061-1067. doi:10.1099/00221287-130-51061

Holt, J. G. (2000). Bergey's manual of determinative bacteriology. (9th ed.). Philadelphia, PA: Lippincott, Williams \& Wilkins.

La Rosa, G., Fratini, M., della Libera, S., Iaconelli, M., \& Muscillo, M. (2012).

Emerging and potentially emerging viruses in water environments. Annali dell'Istituto superiore di sanità, 48(4), 397-406. doi:10.4415/ANN_12_04_07

Lipsky, B. A., Goldberger, A. C., Tompkins, L. S., \& Plorde, J. J. (1982). Infections caused by nondiphtheria corynebacteria. Review of Infectious Diseases, 4(6), 12201235. doi:10.1093/clinids/4.6.1220

Mahaffey, C., Michaels, A. F., \& Capone, D. G. (2005). The conundrum of marine N2 fixation. American Journal of Science, 305(6-8), 546-595. doi:10.2475/ajs.305.68.546

Mylroie, J. R., \& Thoren, L. A. (2007). Variations in coliform bacterial counts on San Salvador, Bahamas. Proceedings of the $11^{\text {th }}$ Symposium on the Natural History of The Bahamas. San Salvador, Bahamas: Gerace Research Center. http://www.geraceresearchcentre.com/pdfs/ 11thNatHist/21_JRMylroieThoren_11thNa tHist.pdf 
Nester, E. W., Anderson, D. G., Evans

Roberts Jr., C., \& Nester, M. T. (2012). Microbiology, a human perspective (7th ed.). New York: McGraw Hill.

Paerl, H. W., Steppe, T. F., Buchan, K. C., \& Potts, M. (2003). Hypersaline cyanobacterial mats as indicators of elevated tropical hurricane activity and associated climate change. AMBIO: A Journal of the Human Environment, 32(2), 87-90. doi:10.1579/0044-7447-32.2.87

Palacios, L., Vela, A. I., Molin, K., Fernández, A., Latre, M. V., Chacón, G., ... \& Fernández-Garayzábal, J. F. (2010). Characterization of some bacterial strains isolated from animal clinical materials and identified as Corynebacterium xerosis by molecular biological techniques. Journal of clinical microbiology, 48(9), 3138-3145. doi:10.1128/JCM.02373-09

Park, L. E. (2012). Comparing two long-term hurricane frequency and intensity records from San Salvador Island, Bahamas. Journal of Coastal Research, 28(4), 891902. doi:10.2112/JCOASTRES-D-1100065.1

Shaklee, R. (1994). In Columbus's footsteps: Geography of San Salvador Island, the Bahamas. San Salvador, Bahamas: Bahamian Field Station.

San Salvador, Bahamas: San Salvador's history. (2013). Retrieved from http://www.the-bahamas.net/theislands/san-salvador-bahamas/.

United States Environmental Protection Agency. (2012). Water contaminant candidate list. Retrieved from

http://water.epa.gov/scitech/drinkingwater/ dws/ccl/ccl3.cfm).

Vos, P., Garrity, G., Jones, D., Krieg, N. R., Ludwig, W., Rainey, F. A., Whitman, W. B. (Eds.). (2009). Bergey's manual of systematic bacteriology, volume 3. (2nd ed.). New York: Springer.

Whitman, W. B., Goodfellow, M., Kämpfer, P., Busse, H.-J., Trujillo, M. E., Suzuki, K.-I., \& Ludwig, W. (Eds.). (2012).

Bergey's manual of systematic bacteriology, volume 5. (2nd ed.). New York: Springer.

World Health Organization. (2014). Global Health Observatory Data Repository. Retrieved from http://apps.who.int/gho/data/node.main.

Yannarell, A. C., Steppe, T. F., \& Paerl, H. W. (2006). Genetic variance in the composition of two functional groups (diazotrophs and cyanobacteria) from a hypersaline microbial mat. Applied and environmental microbiology, 72(2), 12071217. doi:10.1128/AEM.72.2.12071217.2006

Zehr, J. P., Waterbury, J. B., Turner, P. J., Montoya, J. P., Omoregie, E., Steward, G. F., ... \& Karl, D. M. (2001). Unicellular cyanobacteria fix N2 in the subtropical North Pacific Ocean. Nature, 412(6847), 635-638. doi:10.1038/35088063

Zehr, J. P. (2011). Nitrogen fixation by marine cyanobacteria. Trends in microbiology, 19(4), 162-173. doi:10.1016/j.tim.2010.12.004 